\title{
Mutation of a conserved lysine in the kinase homology domain reduces the natriuretic peptide-dependent activity and phosphorylation of guanylyl cyclase-A
}

\author{
Aaron B Edmund, Lincoln R Potter \\ From 7th International Conference on cGMP Generators, Effectors and Therapeutic Implications \\ Trier, Germany. 19-21 June 2015
}

\section{Background and results}

Atrial natriuretic peptide (ANP) and B-type natriuretic peptide (BNP) regulate the cardiovascular system and metabolism by activating the membrane-spanning enzyme, guanylyl cyclase-A (GC-A) [1]. Eight serine and threonine phosphorylation sites have been identified between the membrane-spanning region and the beginning of the kinase homology domain (KHD) of GC-A $[2,3]$. Mutation of four or more of these sites to alanine produced a mutant form of GC-A that could not be activated by ANP, and prolonged exposure to ANP or acute exposure to protein kinase $\mathrm{C}$ activators resulted in the dephosphorylation and inactivation of GC-A $[4,5]$. Despite the clear role of phosphorylation in the regulation of GC-A, it is not known how it is phosphorylated or whether the KHD has intrinsic protein kinase activity. A previous study demonstrated that the K535A missense mutant of GC-A lacks ANP-dependent guanylyl cyclase activity while maintaining a functional catalytic domain, which is consistent with the mutation reducing GC-A phosphorylation [6]. K535 corresponds to an invariant lysine in known protein kinases that forms a salt bridge that stabilizes the $\mathrm{N}$-terminal small lobe of the kinase. In some structures this lysine also interacts with the alpha and beta phosphates of ATP to facilitate substrate positioning. Here, we show first measurements of GC-A protein concentrations based on Coomassie staining and GC-A phosphate concentrations based on ProQ Diamond staining of SDS gels containing immunopurified GC-A to estimate the stoichiometry of the

\footnotetext{
* Correspondence: potter@umn.edu

Department of Biochemistry, Molecular Biology and Biophysics, University of Minnesota, Minneapolis, MN, USA
}

phosphorylation of the K535A mutant compared to wild type GC-A (Figure 1). The initial experiment indicates that K535A-GC-A has a reduced phosphorylation to protein ratio. Additional experiments will be optimized

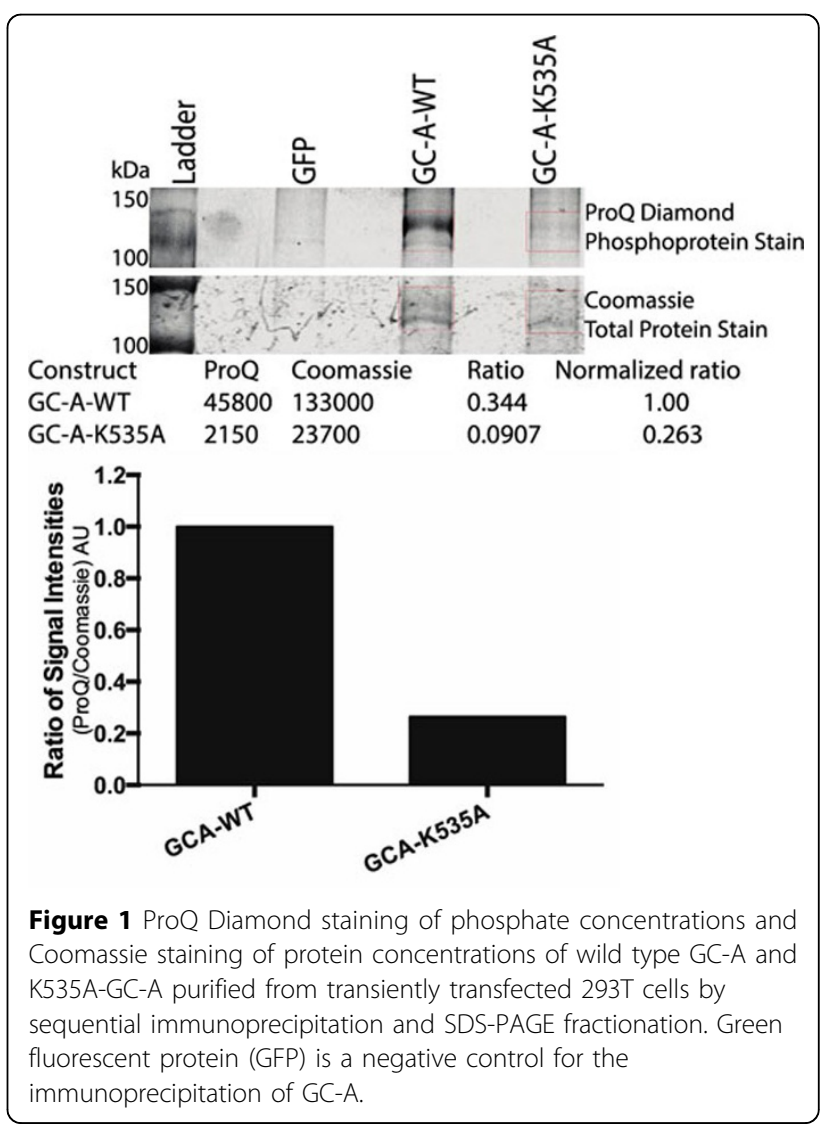


to increase signal to noise and repeated multiple times to determine if the reduced phosphorylation state of the $\mathrm{K} 535 \mathrm{~A}$ mutant is significantly less than that measured for wild type GC-A.

\section{Acknowledgements}

This work was supported by NIH grants R01GM098309 to L.R.P and

T32AR050938 to A.B.E.

Published: 2 September 2015

\section{References}

1. Potter LR: Guanylyl cyclase structure, function and regulation. Cell Signal 2011, 23(12):1921-1926.

2. Schroter J, Zahedi RP, Hartmann M, Gassner B, Gazinski A, Waschke J, Sickmann A, Kuhn M: Homologous desensitization of guanylyl cyclase A, the receptor for atrial natriuretic peptide, is associated with a complex phosphorylation pattern. FEBS J 2010, 277(11):2440-2453.

3. Yoder AR, Stone MD, Griffin TJ, Potter LR: Mass spectrometric identification of phosphorylation sites in guanylyl cyclase a and $B$. Biochemistry 2010, 49(47):10137-10145.

4. Potter $L R$, Garbers DL: Protein kinase C-dependent desensitization of the atrial natriuretic peptide receptor is mediated by dephosphorylation. J Biol Chem 1994, 269(20):14636-14642.

5. Potter $L R$, Hunter $T$ : Phosphorylation of the kinase homology domain is essential for activation of the A-type natriuretic peptide receptor. Mol Cell Biol 1998, 18(4):2164-2172.

6. Antos LK, Potter LR: Adenine nucleotides decrease the apparent Km of endogenous natriuretic peptide receptors for GTP. Am J Physiol Endocrinol Metab 2007, 293(6):E1756-1763.

doi:10.1186/2050-6511-16-S1-A47

Cite this article as: Edmund and Potter: Mutation of a conserved lysine in the kinase homology domain reduces the natriuretic peptidedependent activity and phosphorylation of guanylyl cyclase-A. BMC Pharmacology and Toxicology 2015 16(Suppl 1):A47.

\section{Submit your next manuscript to BioMed Central} and take full advantage of:

- Convenient online submission

- Thorough peer review

- No space constraints or color figure charges

- Immediate publication on acceptance

- Inclusion in PubMed, CAS, Scopus and Google Scholar

- Research which is freely available for redistribution

Submit your manuscript at www.biomedcentral.com/submit 